\title{
T6 - Evaluación del estado trófico de la Laguna de Ayarza utilizando el modelo de simulacion WASP
}

\author{
Andrea E. Rodas-Morán \\ Dirección General de Investigación, Universidad de San Carlos de Guatemala
}

*Autor al que se dirige la correspondencia: andyscreations2012@gmail.com

\section{Resumen}

T os modelos de simulación de calidad de agua, son herramientas ambientales que permiten interpretar y predecir Lla respuesta de un cuerpo de agua a las cargas contaminantes externas. El programa de simulación de calidad de agua (WASP versión 7.41) se utilizó para simular y evaluar la relación entre los nutrientes externos y la calidad de agua, en la Laguna de Ayarza, Santa Rosa, Guatemala. El modelo toma en cuenta dos ciclos de nutrientes (N y $\mathrm{P})$, por medio de variables de calidad de agua: temperatura, nitrato $\left(\mathrm{NO}_{3}\right)$, amonio $\left(\mathrm{NH}_{4}\right)$, nitrógeno total $(\mathrm{TN})$, fosfato $\left(\mathrm{PO}_{4}\right)$, fósforo total (TP), y oxígeno disuelto (OD). El modelo se construyó tomando en cuenta la morfología del lago y las condiciones climáticas. El lago se dividió en siete segmentos, tomando en cuenta los flujos y los parámetros fisicoquímicos para cada uno. Se determinó el coeficiente de dispersión del lago y se calibró utilizando los datos de octubre 2010 a febrero 2011. El post-procesamiento se realizó por medio del software GNUPLOT. Los resultados de la modelación muestran que los valores de fósforo en todo el lago, presentan niveles de eutrofización, los valores de nitrógeno presentan niveles oligotróficos e indican que el lago soporta carga contaminante relativamente alta.

Palabras claves: Calidad de agua, software, Guatemala, laguna

\begin{abstract}
imulation models of water quality are environmental tools that interpret and predict the response of a water body $\checkmark$ to external pollutant loads. The water quality analysis simulation program (WASP version 7.41) was used in this study to simulate and evaluate the relationship between nutrients and external loads in the Ayarza Lake, Santa Rosa, Guatemala. The model takes into account two cycles of nutrients ( $\mathrm{N}$ and $\mathrm{P}$ ) by means of the variables water quality: Temperature, nitrate (NO3), ammonium (NH4), total nitrogen (NT), phosphate (PO 4), total phosphorus (TP) and dissolved oxygen (DO). The model was built taking into account the morphology and weather conditions Lake. The lake was divided into seven segments, with respective flows and physiochemical parameters. The dispersion coefficient was determined and the lake was calibrated using data from October 2010 to February 2011. The post-processing was used by software GNUPLOT. The modeling results show that phosphorus values across the lake have levels of eutrophication, nitrogen levels and indicate that the Lake supports relatively high pollutant load.
\end{abstract}

Keywords: Water quality, software, Guatemala, lake 